\title{
PENILAIAN MUTU ORGANOLEPTIK IKAN MUJAIR (TILAPIA MOSSAMBICA) SEGAR DENGAN UKURAN YANG BERBEDA SELAMA PENYIMPANAN DINGIN
}

\author{
Nurmeilita Taher
}

Staf Pengajar pada Program Studi Teknologi Hasil Perikanan, Fakultas Perikanan dan IImu Kelautan. UNSRAT. Manado 95115.

\author{
ABSTRACT \\ Taher N., 2010. Organoleptic Quality Assessment of Fresh Tilapia Fish \\ (Tilapia mossambica) With Different Size during the Cold Storage \\ Jurnal Perikanan dan Kelautan. Vol VI (1): 8-12.
}

\begin{abstract}
Tilapia fish production is available almost all year round, so fish is easy to obtain and economic value. Use of low temperature $0^{\circ} \mathrm{C}$ on wet fish can prolong the process rigormortis, can suppress bacterial activity, chemical and organoleptic changes. This study aims to determine the effect of different weights to the organoleptic quality of tilapia fish during cold storage. Observations made include a description of the eyes, gills, and texture and odor panel using a team of 15 people. The results showed that weight did not influence the quality of tilapia fish orgnoleptic. And storage of up to 2 days, fish is still fresh classified.
\end{abstract}

Keywords: quality, cold storage, tilapia (Tillapia mossambica).

\section{PENDAHULUAN}

Mutu atau nilai-nilai tertentu yang diinginkan pada suatu material atau jasa (Ilyas, 1983). Ikan segar atau ikan yang baru saja ditangkap, tidak disimpan atau diawetkan dan mutunya masih original. Ikan segar adalah ikan yang masih mempunyai sifat yang sama seperti ikan hidup baik berupa bau dan tekstur (Afrianto dan Liviawati, 1989).

Penggunaan suhu rendah sekitar $0^{\circ} \mathrm{C}$ pada ikan basah/segar dapat memperpanjang proses rigormortis, dapat menekan kegiatan bakteri, kimiawi dan perubahan organoleptik. Dengan demikian penyimpanan pada suhu rendah dan waktu pengolahan cepat menentukan kecepatan penurunan mutu ikan segar setelah ikan mati.

Produksi total ikan mujair mencapai 4.418 ton dengan sentra produksi tersebar di Minahasa, Bolaang Mongondow dan Kotamasya Manado (Anonimous, 2008). Produksi ikan mujair tersedia hampir sepanjang tahun, karena itu ikan ini mudah diperoleh dalam bentuk segar.

\section{METODE PENELITIAN}

Penelitian ini dilakukan di Laboratorium Penanganan dan Pengolahan Hasil Perikanan, Fakultas Perikanan dan IImu Kelautan Unsrat. Metode yang digunakan dalam penelitian ini bersifat eksploratif.

Bahan dan alat yang digunakan adalah ikan mujair segar yang diambil dari tempat budidaya ikan air tawar di desa Tateli kecamatan Dimembe Kabupaten Minahasa Utara. Dengan ukuran berat $\pm 250 \mathrm{gr}$ (kecil) dan $\pm 500 \mathrm{gr}$ (besar). Selanjutnya ikan dimasukkan dalam cool box yang berbeda dan diberi es 1:1.

Setelah itu ikan dibawa ke Laboratorium untuk dilakukan penelitian organoleptik dengan menggunakan score sheet yang sudah disiapkan terlebih dahulu. Penilaian dilakukan pada 0 hari, 2 hari dan 4 hari. Dalam keadaan utuh sampel ikan disajikan sesudah diberi nomor kode. Panelis diminta untuk menilai 
berdasarkan kriteria dan spesifikasi mutu yang disediakan dalam bentuk score sheet organoleptik (tabel 1). Pemberian skor dengan menggunakan tanda $(\sqrt{ })$. Pada jenjang mutu (spesifikasi mutu) menurut Soekarto (1985). Hasil penilaian dari semua panelis ditabulasi dan dilanjutkan dengan penilaian mutu dengan membandingkan jumlah skor hasil penilaian dengan jumlah skor mutu dan persyaratan yang ditetapkan.

Tabel 1. Kriteria Mutu dan Penilaian Organoleptik Ikan Segar (Soekanto, 1985)

\begin{tabular}{|c|c|c|}
\hline Parameter & Kriteria dan Spesifikasi Mutu & Skor \\
\hline \multirow{9}{*}{$\begin{array}{l}\text { Bau } \\
\text { (odor) }\end{array}$} & Segar, berbau rumput laut, spesifik jenisnya & 9 \\
\hline & Bau segar / bau rumput laut mulai menghilang & 8 \\
\hline & Tidak berbau / netral & 7 \\
\hline & Belum ada bau asam, ada bau seperti ikan asin, bau susu & 6 \\
\hline & Berbau susu asam atau seperti susu kental & 5 \\
\hline & Berbau seperti kentang rebus atau seperti bau logam & 4 \\
\hline & Berbau asam asetat, bau rumput / bau sabun & 3 \\
\hline & Bau amoniak mulai tercium & 2 \\
\hline & Bau busuk : amonia, $\mathrm{H}_{2} \mathrm{~S}$, indol & 1 \\
\hline \multirow[t]{6}{*}{$\begin{array}{l}\text { Mata } \\
\text { (eyes) }\end{array}$} & $\begin{array}{l}\text { Bola mata menonjol, pupil hitam cerah, mengkilat, selaput kornea mata } \\
\text { jernih }\end{array}$ & 9 \\
\hline & Bola mata rata, pupil hitam cerah, kornea jernih & 8 \\
\hline & $\begin{array}{l}\text { Bola mata agak cekung, pupil mulai berubah putih susu, kornea agak } \\
\text { keruh }\end{array}$ & 7 \\
\hline & Bola mata agak cekung, pupil putih susu, kornea keruh & 6 \\
\hline & Bola maata cekung, pupil putih susu, kornea keruh & 4 \\
\hline & $\begin{array}{l}\text { Bola mata dan bagian hitamnya tenggelam, tampak lender kuning yang } \\
\text { tebal }\end{array}$ & 1 \\
\hline \multirow[t]{7}{*}{$\begin{array}{l}\text { Insang } \\
\text { (gills) }\end{array}$} & $\begin{array}{l}\text { Warna cemerlang bersih, tanpa lender yang berasal dari bakteri, bau } \\
\text { segar spesifik dengan jenisnya }\end{array}$ & 9 \\
\hline & Warna merah kekuningan, cemerlang tanpa lendir, bau spesifik & 8 \\
\hline & $\begin{array}{l}\text { Insang mulai timbul kepudaran, warna dari merah muda ke merah coklat, } \\
\text { tampak agar berlendir, bau asam nyata }\end{array}$ & 7 \\
\hline & Warna merah agak kusam, lendiri tebal, bau mulai menusuk & 6 \\
\hline & $\begin{array}{l}\text { Perubahan warna lebih nyata, lendir tebal, beberapa lembar insang } \\
\text { menyatu, bau insang lebih busuk }\end{array}$ & 4 \\
\hline & $\begin{array}{l}\text { Warna merah coklat sampai coklat kelabu, tertutup dengan lendir } \\
\text { permukaan }\end{array}$ & 3 \\
\hline & Warna merah coklat sampai kelabu, lendir tebal atau busuk & 1 \\
\hline \multirow[t]{5}{*}{ Tekstur } & Padat, kenyal, sulit menyobek daging dari tulang belakang & 9 \\
\hline & Daging agak lunak, belum ada bekas jari bila ditekan & 7 \\
\hline & Lunak, bekar jari lama hilang, sisik mudah lepas & 5 \\
\hline & Sangat lunak, bekas jari tidak mau hilang kalau ditekan, sisik yang lepas & 3 \\
\hline & $\begin{array}{l}\text { Sangat lunak, sisik banyak yang lepas, daging mudah disobek dari tulang } \\
\text { belakang }\end{array}$ & 1 \\
\hline
\end{tabular}

\section{HASIL DAN PEMBAHASAN}

\section{Pengujian Organoleptik}

Nilai organoleptik dari ikan mujair (Tillapia mossambica) didapat dari hasil penilaian terhadap mata, insang, tekstur, dan bau.

\section{a. Mata}

Dari hasil penilaian organolpetik terhadap mata dari ikan mujair dapat dilihat pada Gambar 1.

Berdasarkan data tersebut, dapat dilihat bahwa nilai rata-rata organoleptik mata untuk ukuran ikan $500 \mathrm{gr}$ pada penyimpanan 0 hari adalah nilai 9 . Hal ini 
menunjukkan bahwa pada penyimpanan 0 hari ikan untuk ukuran $500 \mathrm{gr}$ masih termasuk dalam kategori sangat segar, karena secara organoleptik bola mata masih menonjol, pupil berwarna hitam cerah mengkilap dan kornea selaput mata masih jernih. Sama halnya dengan ikan yang memiliki ukuran berat $250 \mathrm{gr}$, menunjukkan nilai rata-rata 9 , itu berarti ikan yang memiliki ukuran berat $500 \mathrm{gr}$ dan $250 \mathrm{gr}$ pada penyimpanan 0 hari tidak ada perbedaan dan secara organoleptik masih segar.

Pada penyimpanan 2 hari, dari data yang ada menunjukkan bahwa ikan untuk ukuran $500 \mathrm{gr}$ memiliki nilai rata-rata 6,95. Sedangkan untuk ukuran ikan $250 \mathrm{gr}$ memiliki nilai rata-rata 6,90. Secara organoleptik mata mengalami perubahan yaitu bola mata agak cekung, warna pupil mengalami perubahan warna menjadi

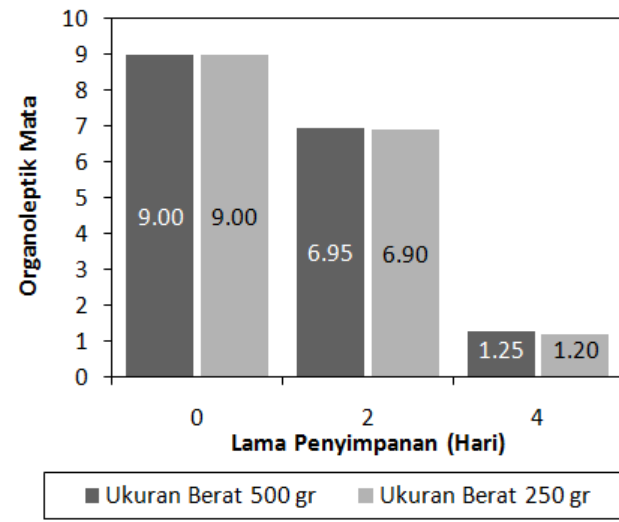

Gambar 1.

Histogram perbedaan lama penyimpanan dan nilai rata-rata organoleptik mata terhadap ukuran berat yang berbeda.

keabu-abuan, dan kornea mata menjadi agak keruh. Hal ini menunjukkan bahwa pada penyimpanan 2 hari secara organoleptik mata mengalami penurunan mutu.

Pada penyimpanan 4 hari, data menunjukkan untuk ukuran ikan $500 \mathrm{gr}$ memiliki nilai rata-rata 1,25 sedangkan untuk ukuran ikan $250 \mathrm{gr}$ memiliki nilai ratarata 1,20 . Dari nilai rata-rata yang ada menunjukkan bahwa secara organoleptik mata telah mengalami perubahan yang sangat nyata yaitu bola mata tampak cekung dan bagian hitamnya tenggelam, tampak pupil berwama putih susu, dan kornea sudah menjadi keruh.

Dari hasil analisa organoleptik mata, dapat disimpulkan bahwa semakin lama penyimpanan maka nilai rata-rata organoleptik semakin menurun. Untuk ukuran berat $500 \mathrm{gr}$ dan $250 \mathrm{gr}$ secara organoleptik mata tidak ada perbedaan, dan pada penyimpanan 4 hari secara organoleptik mata sudah mengalami kemunduran mutu karena nilai rata-rata organoleptik mata sudah tidak bisa diterima lagi dan tidak aman untuk di konsumsi. Menurut llyas (1983), bahwa salah satu akibat dari mulai berkembangnya bakteri adalah mata jadi terbenam dan pudar sinarnya.

\section{b. Insang}

Data hasil penilaian organoleptik terhadap insang ikan mujair segar dapat dilihat pada Gambar 2.

Berdasarkan data tersebut dapat dilihat bahwa nilai organoleptik insang pada penyimpanan 0 hari untuk ukuran berat 500 gr dan ukuran berat $250 \mathrm{gr}$ memiliki nilai rata-rata yang sama yaitu nilai 9 . Dari nilai rata-rata tersebut membuktikan bahwa ikan tersebut masih segar karena insang masih berwarna merah cemerlang, bersih tanpa lendir yang berasal dari bakteri, bau masih segar spesifik dengan jenisnya.

Berdasarkan data selama penyimpanan 2 hari menunjukkan bahwa ikan yang memiliki ukuran $500 \mathrm{gr}$ memiliki nilai rata-rata 6,70 sedangkan untuk ikan yang memiliki ukuran berat $250 \mathrm{gr}$ memiliki nilai rata-rata 6,60 . Secara organoleptik insang mulai timbul kepudaran warna menjadi merah agak kusam yaitu dari merah 
mudah menjadi merah coklat, tampak lendir tebal, bau mulai menusuk dimana bau asam lebih nyata.

Pada penyimpanan 4 hari, insang mengalami perubahan dibandingkan dengan penyimpanan selama 2 hari. Berdasarkan data yang didapat, nilai rata-rata organoleptik untuk ukuran berat ikan $500 \mathrm{gr}$ memiliki nilai rata-rata 1,80 sedangkan untuk ikan yang memiliki ukuran berat $250 \mathrm{gr}$ memiliki nilai rata-rata organoleptik 1,45. Secara organoleptik insang mengalami perubahan warna menjadi merah coklat sampai coklat atau kelabu, tertutup dengan lendir tebal, bau busuk. Secara organoleptik insang, ikan tersebut sudah tidak dapat dikonsumsi lagi.

Menurut Berhimpon (1993), bahwa ikan yang baru ditangkap mengandung mikroba yang secara alami dimana mikroba tersebut terkonsentrasi pada tiga bagian utama yaitu: permukaan kulit, insang, dan isi perut. Jumlah bakteri pada ikan bervariasi tergantung media dimana bakteri itu hidup, yaitu diantara $10^{2}-10^{5} / \mathrm{gr}$ pada kulit, $10^{3}-10^{5} / \mathrm{gr}$ pada insang, dan dapat mencapai $10^{7} / \mathrm{gr}$ pada isi perut. Berdasarkan dari data yang ada, maka dapat dikatakan bahwa perubahan warna pada insang itu dapat terjadi akibat peningkatan jumlah bakteri. Kaitannya dengan penelitian ini, perubahan nilai organoleptik pada insang mengalami penurunan nilai rata-rata secara drastis terjadi pada penyimpanan hari ke empat.

\section{c. Tekstur}

Data hasil penelitian organoleptik tekstur pada ikan mujair (Tillapia mossambica) dapat dilihat pada Gambar 3.

Berdasarkan data yang ada dapat dilihat bahwa nilai rata-rata organoleptik tekstur pada penyimpanan 0 hari untuk ikan yang memiliki ukuran berat $500 \mathrm{gr}$ mempunyai nilai rata-rata 9 , sama halnya dengan ikan yang memiliki ukuran berat 250 gr yang mempunyai nilai rata-rata 9. Dari nilai rata-rata tersebut dapat dikatakan bahwa pada penyimpanan 0 hari secara organoleptik tekstur ikan dikategorikan sangat segar karena memiliki tekstur yang masih padat dan kenyal, sulit menyobek

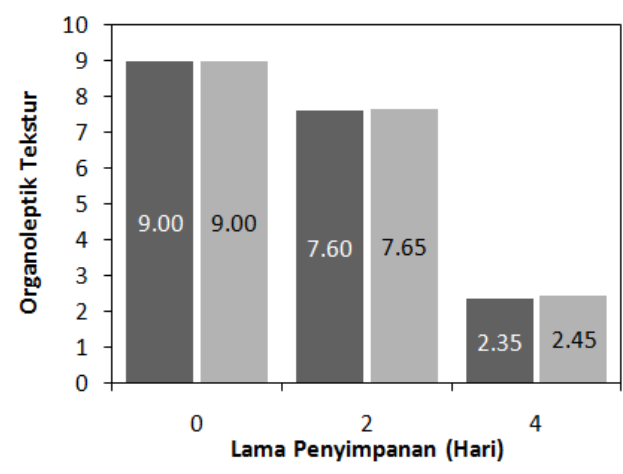

a Ukuran Berat $500 \mathrm{gr}$ Ukuran Berat $250 \mathrm{gr}$

Gambar 3.

Histogram perbedaan lama penyimpanan dan nilai rata-rata organoleptik tekstur terhadap ukuran berat yang berbeda. daging dad tulang belakang.

Pada penyimpanan 2 hari, dari data yang ada memiliki nilai rata-rata tekstur untuk ikan yang memiliki ukuran berat $500 \mathrm{gr}$ mempunyai nilai rata-rata 7,60 dan untuk ikan yang memiliki ukuran berat $250 \mathrm{gr}$ mempunyai nilai rata-rata 7,65. Dari data tersebut dapat dilihat bahwa tidak ada perbedaan antara ukuran berat $500 \mathrm{gr}$ dan $250 \mathrm{gr}$. Secara organoleptik tekstur daging agak lunak, sisik mulai mudah terlepas, tetapi bila ditekan belum ada bekas jari.

Pada penyimpanan 4 hari, data menunjukkan bahwa nilai rata-rata tekstur untuk ukuran berat $500 \mathrm{gr}$ memiliki nilai rata-rata organoleptik 2,35 dan ikan yang memiliki ukuran berat $250 \mathrm{gr}$ memiliki nilai rata-rata 2,45. Secara organoleptik tekstur sangat lunak, bekas jari tidak mau hilang, sisik banyak yang lepas, daging mudah disobek dari tulang belakang. Dari hasil pengamatan organoleptik tekstur selama penyimpanan 4 hari, menunjukkan bahwa pada penyimpanan 4 hari ikan sudah tidak dapat dikonsumsi dan masuk dalam kategori ditolak. Menurut Berhimpon (1993) bahwa, perubahan tekstur dimana daging menjadi lebih lunak terjadi apabila ikan sudah mulai mengalami kemunduran mutu. Hal ini disebabkan oleh mulai terjadinya perombakan pada jaringan otot daging oleh proses enzimatis. 


\section{d. Bau}

Data nilai organoleptik bau ikan mujair dapat dilihat pada Gambar 4.

Berdasarkan nilai rata-rata organoleptik bau tertinggi diperoleh pada penyimpanan 0 hari dengan nilai 9 sedangkan nilai rata-rata terendah diperoleh pada penyimpanan 4 hari dengan nilai 1,30.

Berdasarkan data tersebut dapat dilihat bahwa pada penyimpanan 0 hari untuk ikan yang memiliki ukuran berat 500 gr dan $250 \mathrm{gr}$ memiliki nilai rata-rata organoleptik bau yang sama. Hal ini membuktikan bahwa pada penyimpanan 0 hari secara organoleptik bau ikan tersebut masih digolongkan dalam ikan segar.

Dari data penyimpanan selama 2 hari

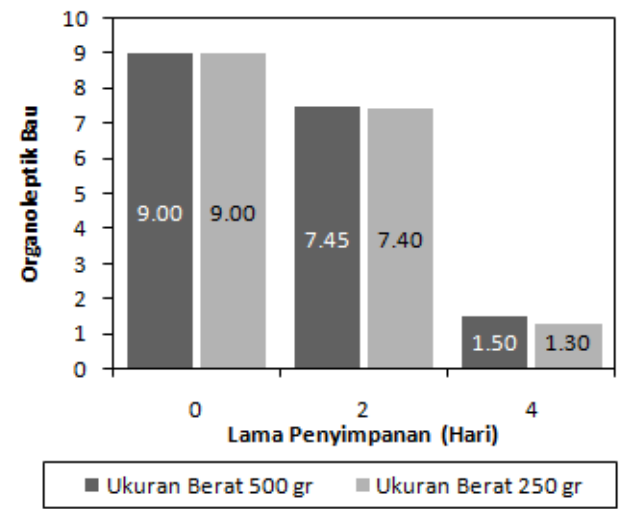

Gambar 4.

Histogram perbedaan lama penyimpanan dan nilai rata-rata organoleptik bau terhadap ukuran berat yang berbeda. menunjukkan bahwa ikan yang memiliki ukuran berat $500 \mathrm{gr}$ mempunyai nilai ratarata organoleptik bau 7,45. Sedangkan untuk ikan dengan ukuran berat $250 \mathrm{gr}$ mempunyai nilai rata-rata 7,4 . Secara organoleptik bau segar sudah mulai menghilang, belum ada bau asam. Secara umum, nilai rata-rata tersebut cukup berimbang. Pada penyimpanan 4 hari, data menunjukkan bahwa ikan yang memiliki ukuran berat $500 \mathrm{gr}$ mempunyai nilai rata-rata 1,5 , sedangkan untuk ukuran berat 250 gr mempunyai nilai rata-rata 1,3. Hal ini menunjukkan bahwa secara organoleptik bau sudah mulai tercium bau busuk dan bau amoniak dan memiliki kesan ditolak oleh panelis. Menurut Ilyas (1983) bahwa, pembusukkan pada ikan lebih bersifat ketengikan oksidatif. Perubahan ini terjadi akibat oksidasi lemak sehingga menimbulkan bau tengik yang tidak diinginkan.

\section{KESIMPULAN}

Hasil penilaian mutu organoleptik ikan mujair (Tilapia mossambica) segar untuk ukuran berat $500 \mathrm{gr}$ dan $250 \mathrm{gr}$ tidak meunjukkan perbedaan yang nyata. Pada penyimpanan hingga hari ke 2 ikan masih dikategorikan segar, sedangkan pada penyimpanan 4 hari ikan sudah dikategorikan ditolak.

\section{DAFTAR PUSTAKA}

Afrianto E. dan E. Liviawati, 1989. Pengawetan dan Pengolahan Ikan. Kanisius. Jakarta.

Anonimous, 2008. http://suharjawanasuria.tripod.com/sulawesi_utara.htm

Berhimpon S., ljong F. G. Monoharapon. T., 2002. Penuntun Praktikum Penilaian Indera. Laboratorium Penanganan dan Pengolahan Hasil Perikanan. Fakultas Perikanan dan IImu Kelautan Universitas Sam Ratulangi. Manado.

llyas, S. 1983. Teknologi Refrigerasi Hasil Perikanan 1, Teknik Pendinginan Ikan. Paripurna. Jakarta.

Berhimpon, S. 1993. Mikrobiologi Perikanan Ikan. Bagian 1. Ekologi dan Pertumbuhan Mikroba Serta Pertumbuhan. Biokimia Pangan. Laboratorium Pengolahan dan Pembinaan Mutu Hasil Perikanan. Fakultas Perikanan dan IImu Kelautan. Universitas Sam Ratulangi. Manado.

Soekarto, S. 1985. Penilaian Organoleptik Untuk Industri Pangan dan Hasil Pertanian. 